\title{
Teaching and Learning English in Costa Rica: A Critical Approach ${ }^{1}$
}

\section{(Enseñanza y aprendizaje del español en Costa Rica: enfoque crítico)}

\author{
Ana Solano Campos ${ }^{2}$ \\ Emory University, Estados Unidos
}

\begin{abstract}
English teaching programs, particularly in foreign language contexts focus on linguistic and methodological aspects rather than on ideological ones, in spite of their importance to examine the political nature of teaching and learning English because it connects language classrooms to larger social dynamics. Critical applied linguistics is an approach that addresses "questions of power, difference, access, and domination," and how they are produced. This articles explores the social, national, and global forces that shape English language teaching in Costa Rica.
\end{abstract}

\section{resumen}

Los programas de enseñanza del inglés, en especial los de su enseñanza como idioma extranjero, se centran en aspectos linguiísticos y metodológicos; no en los ideológicos, no obstante su importancia para analizar las relaciones entre aspectos pedagógicos y procesos sociales dinámicos más extensos. La lingüística aplicada crítica estudia «cuestiones de poder, diferencia, acceso y dominación» y la manera en que estos elementos se producen. Se exploran las fuerzas sociales, nacionales e internacionales que dan forma a la enseñanza y adquisición del inglés en Costa Rica.

1 Elaborado con base en la ponencia presentada por la autora en el IV Congreso Internacional de Lingüística Aplicada, llevado a cabo en mayo de 2013, en el Campus Omar Dengo, de la Universidad Nacional de Costa Rica. Recibido: 19 de mayo de 2012; aceptado: 30 de agosto de 2012.

2 Correo electrónico: atsolan@emory.edu

$$
L_{\text {etras }} 52 \text { (2012), ISSN 1409-424X }
$$


Keywords: Critical Applied Linguistics, second language teaching and learning, Teaching English as a Foreign Language (TEFL).

Palabras clave: linguística aplicada critica, aprendizaje y adquisición de segundas lenguas, enseñanza del inglés como idioma extranjero.

"Language is deeply political, and the goals of one's work as a (critical) applied linguist are to uncover the operations by which the political nature of language is obscured and to reveal the political implications of language." Pennycook ${ }^{3}$

By emphasizing the methodological and linguistic aspects of language learning and teaching, but neglecting the ideological ones, English programs around the world have, albeit unintentionally, perpetuated myths about the "neutrality" of the English teaching and learning endeavor, about the primacy of the English language, and about the historical and geopolitical context of English. However, Graddol reminds us that the spread of English is the result of "the colonial expansion of Britain," and of the political, economic, and cultural influence of the United States. ${ }^{4}$ As a colonial language, English has been associated with high socioeconomic status and placed at the top of language hierarchies, becoming a valued commodity. As the language of commerce, travel, research, higher education, and technology, "English is widely regarded as a gateway to wealth for national economies, organizations, and individuals." ${ }^{5}$ Thus, nations endorsing neoliberal values have equated the English proficiency of their citizens with desirable competitiveness in the global market. In

3 Alastair Pennycook, The Cultural Politics of English as an International Language (London: Longman, 1994).

4 David Graddol, The Future of English? A Guide to Forecasting the Popularity of the English Language in the 21st Century (London: The British Council, 2000) 14.

5 Graddol, 38 . 
fact, Graddol suggests that it is likely that "the distribution of poverty in the future will be closely linked to the distributions of English."

In the English frenzy, educational institutions around the globe have worked diligently to meet the demand for the growing numbers of English learners. In this article, I look at Critical Applied Linguistics as a framework to both unveil and utilize the political aspect of English teaching and learning. I argue that English teaching professionals can create classrooms where English serves more than a linguistic or communicative function: a social function. I start by providing a synthesis of Critical Applied Linguistics and its importance for EFL courses. Then, I give an overview of English teaching and learning in Costa Rica, and conclude by giving recommendations for incorporating a critical perspective in language activities in the classroom.

\section{What is Critical Applied Linguistics?}

For Pennycook, Critical Applied Linguistics is an intersection of domains that, through a careful evaluation, extends the ways in which we approach translation, language teaching, language testing, language planning, language rights, and literacy to other social and political domains. Critical applied linguistics "focuses on questions of power, difference, access, and domination"7 through praxis, interdisciplinarity, social inquiry, and self-reflexivity. The concepts of linguicism and linguistic imperialism are instrumental in operationalizing the political dimension of language, and in this particular context, of English.

Macedo, Dendrinos, and Gounari define linguicism as "a sort of 'linguistically argued racism'... a process by which an unequal division of power is produced and maintained according to

6 Graddol, 38.

7 Alastair Pennycook, Critical Applied Linguistics: A Critical Introduction (Mahwah, NJ: Erlbaum, 2001) 21 . 
a division between groups on the basis of the language that they speak." ${ }^{\prime}$ Linguicism is just one phenomenon contributing to what Macedo et al. call linguistic imperialism, or "the dominant role of English in the world today [which] is maintained and promoted through a system both of material or institutional structures... and of ideological positions." Although critical perspectives such as this tend to stress the negative aspects of the spread of English as an international language and lingua franca, Pennycook has highlighted that from a global Englishes perspective, an examination of English teaching and learning "seeks to understand the role of English both critically-in terms of new forms of power, control and destructionand in its complexity-in terms of new forms of resistance, change, appropriation and identity." 10

So, why is a Critical Applied Linguistics approach important? Through a Critical Applied Linguistics framework, teachers and students can engage in questions about the nature and intersections of language and privilege in society. For example, speakers of English as a foreign language have continuously been discriminated against because of their "non-native" accents. However, today, over 750 million individuals speak English as a Foreign Language (EFL), almost double the number of first language speakers (375 million) or second language speakers (375 million) of English. ${ }^{11}$ In light of this information, students and teachers can ask themselves, as have scholars who study World Englishes, whether the idea of "nativeness" and of "ownership" of English should be redefined to acknowledge and affirm the many different English uses and accents that exist worldwide. Providing spaces to ask and seek answers for questions like these, strengthens students' abilities to engage in conversations of

8 Donaldo Macedo, Bessie Dendrinos, and Panayota Gounari, The Hegemony of English (Boulder, CO: Paradigm Publishers, 2003) 61.

9 Macedo et al., 61.

10 Alastair Pennycook, Global Englishes and Transcultural Flows (New York: Routledge, 2007) 5.

11 David Graddol, English Next (London: The British Council, 2006) 10. 
national and global interest and is crucial for the development of their agency and civic participation.

\section{Genesis and Evolution of English Teaching and Learning in Costa Rica}

A conversation about teaching English critically in Costa Rica cannot take place without providing the pertinent historical context to inform recent and future developments in the field, particularly because decisions regarding the teaching of English have been shaped by global economic and political processes. According to Chaves, Solano, and Villalobos:

[1]os objetivos y las metodologías de enseñanza del inglés han ido cambiando de acuerdo con los sistemas de producción de ingresos del país: de una sociedad basada en la oligarquía cafetalera, a una basada en el turismo y compañías multinacionales. Se ha percibido entonces el énfasis en la naturaleza "corporativa" del inglés en donde la oferta y la demanda de este idioma guían los objetivos de la enseñanza del mismo. ${ }^{12}$

English teaching in Costa Rica started as early as the mid-nineteenth century and was first institutionalized in 1825 in the internal bylaws of the Casa de Enseñanza Santo Tomás. ${ }^{13}$ Bonilla and Rojas tell us that by that time Costa Rica was already engaging in commerce with foreign countries, such as England; they state that "the need to learn the English language for commercial and productivity reasons arose from these trade relations between Costa Rica and

12 OIga Chaves Carballo, Ana Solano Campos and Nuria Villalobos Ulate, "En búsqueda de la responsabilidad social en la clase de Inglés," Relaciones Internacionales 77-78 (2009): 53-64.

13 Patricia Córdoba Cubillo, Rossina Coto Keith, and Marlene Ramírez Salas, "La enseñanza del Inglés en Costa Rica y la destreza auditiva en el aula desde una perspectiva histórica," Revista Electrónica Actualidades Investigativas en Educación 5, 2 (2005): 1-12. 
other English speaking countries or countries where Spanish was not spoken" (my translation). ${ }^{14}$

Records of English instruction in primary schools go back to the 1940s, ${ }^{15}$ but English classes were already included in academic programs upon the founding of the "colegios primario-secundarios" in $1887 .{ }^{16}$ Córdoba, Coto, and Ramírez also report that English classes were initially taught by foreigners, presumably native speakers of English, and it was not until 1954 when the first training of English teaching professionals took place at the Universidad de Costa Rica (UCR). It was also UCR which launched the first English teaching program in 1957. In 1973, the Universidad Nacional, along with the Escuela de Literatura y Ciencias del Lenguaje, opened its doors, ${ }^{17}$ also becoming a central actor in the "training and preparation of professionals in the areas of linguistics, literature, second language teaching, and translation in Costa Rica." 18

Bonilla and Rojas posit that by the late 1980s, the construction of the railroad and the growth of the United Fruit Company promoted a stronger support of English instruction. Over a decade later, in 1994, the Política Educativa Hacia el Siglo xxi established foreign language teaching as essential for cultural exchange and understanding. ${ }^{19}$ In 1995, the Programa de Estudios de Lenguas Extranjeras para el Desarrollo (PROLED) was launched. ${ }^{20}$ Still, Córdoba, Coto, and Ramírezexplain that up tothe late 1990s English wasconsidered

14 Álvaro Bonilla Lynch and Roberto Rojas Alfaro, "El aprendizaje de lenguas extranjeras como herramienta del desarrollo humano," Congreso Iberoamericano de las Lenguas en la Educacion y en la Cultura/IV Congreso Leer.es (2012) 3.

15 Edwin Marín Arroyo, "Cronología de la enseñanza del Inglés en Costa Rica durante el siglo xx," Revista Comunicación 21, 1 (2012): 4-15 (14).

16 Córdoba et al., 3.

17 "Algunos hitos de la Historia de la Escuela de Literatura y Ciencias del Lenguaje." Escuela de Literatura y Ciencias del Lenguaje. Universidad Nacional, n.d. Web. 3 March 2013.

18 Olga Chaves Carballo, Ana Solano Campos, and Nuria Villalobos Ulate, "In the Search for Social Justice: Implementing Critical Pedagogy in the Language Classroom," Linguagem \& Ensino 13, 2 (2010): 415-434.

19 Roxy Calderón and Yinnia Mora, "Formación permanente del docente de Inglés. Una experiencia exitosa en Costa Rica," REICE 10, 4 (2012): n.p.

20 Marín, 13. 
a special subject (asignatura especial), like art, music, and physical education. It was not until 1997 that English was established as a basic subject (materia básica) or content area, in primary school, making Costa Rica the only country in Central America with an English program at that level.

Marín argues that the proliferation of foreign investment companies in Costa Rica during the 1990s prompted the modification of curricular plans in both public and private universities. ${ }^{21}$ This proliferation of foreign investment, the result of global neoliberal tendencies, along with a growing and thriving tourist industry also influenced the emergence of great numbers of private "bilingual" schools, language institutions, and higher education English courses offerings. More recently, in 2008, the government approved decrees $\mathrm{N}^{\circ}$ 34535-MP-MEP-COMEX and $\mathrm{N}^{\circ}$ 34425-MEP-COMEX to officially declare English learning and teaching as a matter of national interest and to support the creation of the Fundación Costa Rica Multilingüe, an entity in charge of leading language instruction across the country. Such recognition of English teaching and learning as a national priority is arguably a first in the country's history.

Today, there are several English teaching preparation programs in Costa Rica offered by both public and private universities. These programs focus largely on pedagogical and linguistic elements, with ideological considerations being kept at the margin or occasionally addressed in courses like sociolinguistics and dialectal variations. Thus, the challenge to incorporate critical perspectives into English teaching preparation programs is urgent. Like Bartolome, I invite teachers of English to "dare to infuse ideology into language-teacher education" ${ }^{22}$ and into language education in general as well.

21 Marín, 13-14.

22 Lilia Bartolome, "Daring to Infuse Ideology into Language-Teacher Education," S. May and C. Sleeter, Critical Multiculturalism: Theory and Praxis (New York: Routledge, 2010) 47-59 (47). 


\section{Teaching and Learning English Critically}

Language learning should provide students with what Banks calls healthy cultural, national, and global identifications:

Schools should help students understand how cultural, national, regional, and global identifications are interrelated, complex, and evolving. These identifications are interactive in a dynamic way. Each should be recognized, valued, publicly affirmed, and thoughtfully examined in schools. Students should be encouraged to critically examine their identifications and to understand the complex ways in which they are interrelated and constructed. ${ }^{23}$

In the EFL classroom, to achieve the transformative education that Banks discusses, I propose using Pennycook's ${ }^{24}$ unifying themes for critical approaches to TESOL (Table 1), which are also appropriate for the EFL context. Pennycook posits that a critical approach to TESOL should include a consideration of the domains, transformative pedagogies, and self-reflexive skills necessary to create connections among micro and macro social actors (such as the language classroom and the nation-state, respectively) to critique inequality and search avenues for the transformation of that inequality.

23 James Banks, Multiethnic Education: Theory and Practice (Boston, MA: Allyn and Bacon, 2004) 134.

24 Alastair Pennycook, "Critical Approaches to TESOL," TESOL Quarterly 33, 3 (1999): 329-348. 


\section{Table 1. Pennycook's Unifying Themes for a Critical Approach to TESOL}

\begin{tabular}{|l|l|}
\hline Theme & Guiding Question \\
\hline Domain & $\begin{array}{l}\text { To what extent do particular domains define } \\
\text { a critical approach? How do they connect the } \\
\text { microrelations of the classroom to broader } \\
\text { social and political relations? }\end{array}$ \\
\hline $\begin{array}{l}\text { Focus on issues of class, gender, race, sexuality, ethnicity, representations of } \\
\text { Otherness (unequal pay, access to jobs, access to education, distribution of } \\
\text { resources, access to technology, discrimination, prejudice, intersectionality) }\end{array}$ \\
\hline Transformative Pedagogy & $\begin{array}{l}\text { How does the particular approach to education } \\
\text { hope to change things? }\end{array}$ \\
\hline $\begin{array}{l}\text { Focus on creating awareness, providing pedagogical responses to forms of } \\
\text { difference (giving marginalized student's access to mainstream, transforming } \\
\text { the mainstream by emphasizing inclusivity, level of engagement with } \\
\text { questions of difference, curricular or pedagogical inclusivity, including } \\
\text { difference as social issue, exploring difference from historical perspective) }\end{array}$ \\
\hline $\begin{array}{l}\text { Self-reflexive Stance on } \\
\text { Critical Theory }\end{array}$ & $\begin{array}{l}\text { To what extent does the work constantly question } \\
\text { common assumptions, including its own? }\end{array}$ \\
\hline $\begin{array}{l}\text { Focus on forms of critical theory to think about social structure, knowledge, } \\
\text { politics, the individual, or language; constant skepticism, a constant } \\
\text { questioning about the types of knowledge, theory, practice, or praxis }\end{array}$ \\
\hline
\end{tabular}

Adapted from Pennycook (“Critical Approaches,” 331-345).

For Pennycook, English teaching professionals must make decisions on whether they will approach a transformative pedagogy in the English classroom by 1) creating awareness of structural and individual forms of inequality, 2) focusing on issues of access of underrepresented populations, 3) emphasizing inclusivity, or 4) stressing difference as a social issue. This can be achieved by promoting pedagogical inclusivity and by making curricular modifications or additions to incorporate activities that strengthen learners' knowledge of themselves, their origins, and of the world around them. 
Thus, a consideration of Pennycook's unifying themes involves making content modifications, particularly using authentic materials that address social justice issues. It also requires educators to demonstrate and facilitate critical pedagogy. The resources in Table 2 are a select list of websites that include content, activities, and in some cases teachers' guides that can facilitate the inclusion of social justice issues in the ELF classroom.

\section{Table 2. Online Resources for Critical English Teaching and Learning}

\begin{tabular}{|c|c|c|c|c|c|}
\hline & Resource & $\mathbf{R}^{*}$ & $\mathbf{W}^{*}$ & $\mathbf{L}^{*}$ & $\mathrm{~S}^{*}$ \\
\hline 1 & $\begin{array}{l}\text { Teaching Tolerance } \\
\text { http://www.tolerance.org/ }\end{array}$ & $\sqrt{ }$ & $\sqrt{ }$ & $\sqrt{ }$ & $\sqrt{ }$ \\
\hline 2 & $\begin{array}{l}\text { Race: The Power of an Illusion } \\
\text { http://www.pbs.org/race/000_General/000_00- } \\
\text { Home.htm }\end{array}$ & $\sqrt{ }$ & & $\sqrt{ }$ & \\
\hline 3 & $\begin{array}{l}\text { The Zinn Education Project } \\
\text { http://zinnedproject.org }\end{array}$ & $\sqrt{ }$ & $\sqrt{ }$ & $\sqrt{ }$ & $\sqrt{ }$ \\
\hline 4 & $\begin{array}{l}\text { Edutopia } \\
\text { http://www.edutopia.org/ }\end{array}$ & $\sqrt{ }$ & & $\sqrt{ }$ & $\sqrt{ }$ \\
\hline 5 & $\begin{array}{l}\text { TED Talks } \\
\text { http://www.ted.com/talks }\end{array}$ & $\sqrt{ }$ & & $\sqrt{ }$ & \\
\hline 6 & $\begin{array}{l}\text { Do you Speak American? } \\
\text { http://www.pbs.org/speak/ }\end{array}$ & $\sqrt{ }$ & & $\sqrt{ }$ & \\
\hline 7 & $\begin{array}{l}\text { The New Americans } \\
\text { http://www.pbs.org/independentlens/ } \\
\text { newamericans/ } \\
\text { foreducators_lesson_plan_11.html }\end{array}$ & $\sqrt{ }$ & $\sqrt{ }$ & $\sqrt{ }$ & $\sqrt{ }$ \\
\hline 8 & $\begin{array}{l}\text { TESOL Social Responsibility Interest Section (SRIS) } \\
\text { http://newsmanager.commpartners.com/tesolsris/ } \\
\text { issues/2013-02-21/email.html }\end{array}$ & $\sqrt{ }$ & $\sqrt{ }$ & & \\
\hline 9 & $\begin{array}{l}\text { NNEST of the Month Blog } \\
\text { http://nnest.blog.com/ }\end{array}$ & $\sqrt{ }$ & $\sqrt{ }$ & & \\
\hline
\end{tabular}

*Reading (R), Writing (W), Listening (L), Speaking (S). 
Most of the items in the websites presented in Table 2 include articles, videos, and recordings that highlight social justice issues, underrepresented voices, or different perspectives of a historical event. In particular, these resources have the potential to inform learners of the realities of life in English speaking countries like the United States and of the historical and contemporary connections among nations. Three strategies to keep in mind when using these resources to implement Pennycook's unifying themes are: 1) providing historical context, 2) making interdisciplinary connections, and 3) approaching the materials comparatively. In the following paragraphs, I expand on each of these strategies.

\section{Historical Perspectives}

Context is one of the most critical elements for understanding a linguistic event or utterance. In addition to linguistic and social context, historical context is essential to understand various forms of popular and academic communication. Drawing from the field of history, skills such as historical thinking, what Salinas, Blevins, and Sullivan describe as "an examination of a historical event or figure through the 'reading' of primary sources or first-hand accounts," ${ }^{25}$ can enhance students comprehension of the myriad of narratives embedded in texts written in English. Historical thinking, the authors argue, "creates an opportunity to include multiple perspectives and/or challenge traditional metanarratives." ${ }^{26}$ Critical historical thinking posits that "we [educators and students] not only question why and how knowledge is constructed, but also examine why and how some knowledge is privileged and honored while other knowledge is marginalized." ${ }^{27}$

Historians also carefully look at how identity and society influence knowledge construction and dissemination of knowledge. They

25 Cinthia Salinas, Brooke Blevins and Caroline C. Sullivan. "Critical Historical Thinking: When Official Narratives Collide with Other Narratives," Multicultural Perspectives 14, 1 (2012): 18-27 (18).

26 Salinas et al., 18.

27 Salinas et al., 19. 
look at how a particular time period or event might have shaped an individual's understanding of historical events. They carefully examine the point of view of the speaker, writer, or communicator; for example, they examine whether the author had a conflict of interest or particular investment in the topic. They also study the patterns and trends in history reporting over time, identifying the continuities and gaps among different ideologies.

When using the resources in Table 2, providing historical context means prompting students to examine an issue from different points of view, from different sources, and from different time periods. For example, if the topic is immigration, both the teacher and the students should ask themselves what students are more likely to read about immigration in a U.S. newspaper? What would they read in an English-based Costa Rican newspaper? What would they read in an article published by a Costa Rican scholar in Spanish and translated into English? How is the same issue addressed in the different newspapers? How has the treatment of immigration changed or remained the same in different time periods? How has the language used to discuss immigration changed or remained the same? What national and international events influenced the authors of the different sources?

\section{Interdisciplinary Approaches}

The use of critical historical thinking in language classrooms is an example of transdisciplinarity. Crossing disciplinary boundaries is a skill that has become increasingly important. In a time when innovation and creativity are praised, original solutions and understandings of the world are unlikely to reside in just one field. The popularity of English provides learners an unprecedented opportunity to access resources from many fields of study and engage in interdisciplinary relationships and queries. Learning to express complex ideas about varying social phenomena, grounded in transdisciplinary knowledge and critical analysis of information, is as important a task 
as learning how to express those ideas. In addition, transdisciplinarity is at the core of STEAM (Science, Technology, Engineering, Arts, and Mathematics), a technology-driven approach to education that seeks to strengthen the abilities of learners to participate and compete in an information and technology-based global market.

Not only does the integration of different disciplines enable individuals to participate in the global economy, it can also help them to debunk strongly held stereotypes and narratives about the world. For instance, the perceived, yet erroneous, "inferiority" of African American Vernacular English, or Ebonics, is not only a product of people's lack of knowledge about the linguistic characteristics of that particular English variety, but also a product of scientific theories such as eugenics, a movement towards "racial purity," that linked skin color and race with desirable traits such as intelligence (or lack thereof). It has taken many years for scientists (both in the natural sciences and in the social sciences) to come to terms with the fact that race is a social construction and does not have a genetic basis. Resources like the ones in "Race: The Power of an Illusion" by the Public Broadcasting Company (PBS), in Table 2, utilize contemporary advances in science to refute arguments about the superiority of any one racial group. In using the variety of multimedia tools in the site, students can engage with particular words and language forms used in conversations about racial inequality and racism.

\section{Comparative Viewpoints}

The word compare is said to have originated from the Latin "compare," or to make equal. Yet the act of comparing often implies making two or more things different. Comparisons that forgo interdisciplinary, historical, and contextual factors and focus exclusively on outcomes or indiscriminate borrowing of education policies are often problematic. For instance, standardized measures of academic achievement across countries, such as the Program for International Student Assessment (PISA), regularly affirm negative views of 
developing countries while confirming the academic advantage of so called "first-world nations." How can we accurately measure academic achievement across countries when each country has such a different socio-economic, cultural, and historical background? How accurate can these measures of achievement be? The kind of comparative approach that I suggest involves an emphasis on process and context, with a careful look at historical events (such as colonialism) and social dynamics (such as colorblindness).

Language learning is inherently a comparative activity. It allows us to examine how different world perspectives and values, as well as our own, are put into symbols in new and exciting ways and given particular meanings. A comparative perspective to language learning provides the opportunity to examine the challenges, similarities, and potential for positive action of different sociolinguistic realities in particular geopolitical settings. In fact, Phillips and Schwesifurth suggest that comparative inquiry "serves to combat provincialism and ethnocentricity, to motivate the study of the history and development of school systems, and to increase awareness of the interplay between schools and their social environments;" they also suggest that "it is through the act of comparing that we define our position on most issues that require exercising of judgment."28

Implementing a comparative perspective in the EFL classroom might involve using English to examine how different phenomena are addressed in different countries. For instance, if engaging in conversations about migration patterns, students could compare migration patterns in Costa Rica and the United States. Using English, students could look at the immigration patterns in both countries during different time periods, study immigration legislation in each country, study the reaction to immigration growth in the population in each country, and examine whether any education policies have been implemented to address the needs of migrant populations. Students

28 David Phillips and Michele Schweisfurth, Comparative and International Education: An Introduction to Theory, Method, and Practice (New York: Continuum, 2007) 14. 
could also design initiatives to address the educational challenges of immigrant children.

\section{Concluding Remarks}

Bartolome reminds us that "before teachers can raise their students' critical understanding of racial, gender, and class differences, the teachers themselves must first be able to engage in this type of critical analysis" ${ }^{29}$; she continues:

A first step in developing political clarity is to understand that schools are ideological sites of struggle and, as such, are not politically neutral. Given the impossibility of neutrality in educa- tion, one way to ensure that ESL/SE teachers develop political and ideological clarity is by having teacher preparation curricula explicitly explore how ideology functions to hide the asymme- tries of power relations and the distribution of both cultural and economic capital.

English teaching preparation programs need to be modified to include opportunities for instructors and students to develop skills for the critical analysis of reality, and in this case in particular, of our linguistic reality. These programs should also prepare students to challenge linguistic narratives and processes that perpetuate stereotypes and oppression of any kind.

There are more people in the world today that speak English as a foreign language than those who speak it as a first or second language. The rise and continuous growth of English into an international language has potential for both oppression or transformation. Here I have explored how a Critical Applied Linguistics approach to English teaching might help achieve the latter. From a global Englishes perspective and implementing Pennycook's

29 Bartolome, 48. 
Unifying Themes for a Critical Approach to TESOL, I have suggested three strategies and a series of online resources that can aid English teaching professionals in the creation of their own critical language pedagogy. By incorporating critical historical thinking, transdisciplinarity, and comparative perspectives of social justice issues into their lessons, English teaching professionals can begin to join the pragmatic and theoretical aspects of English teaching into a professional praxis that goes beyond main perpetuation of economic and political structures and ventures. 